\title{
Intake, digestibility, and ruminal parameters of Nellore bulls supplemented with increasing levels of crude glycerin in Brachiaria Brizantha pastures
}

Consumo, digestibilidade e parâmetros ruminais de machos Nelore não castrados suplementados com níveis crescentes de glicerina bruta em pastagens de "Brachiaria brizantha"

\author{
POSSAMAI, Adriano Jorge ${ }^{1}$; ZERVOUDAKIS, Joanis Tilemahos ${ }^{1}$; HATAMOTO- \\ ZERVOUDAKIS, Luciana Keiko ${ }^{1}$; FREIRIA, Lucien Bissi da ${ }^{1 *}$; SILVA, Pedro Ivo \\ José Lopes da Rosa ${ }^{1}$; MELO, Alan Barbosa ${ }^{2}$
}

\footnotetext{
${ }^{1}$ Universidade Federal do Mato Grosso, Faculdade de Agronomia e Zootecnia, Programa de PósGraduação em Ciência Animal, Cuiabá, Mato Grosso, Brasil.

${ }^{2}$ Universidade Estadual Paulista, Faculdade de Ciências Agrárias e Tecnológicas, Programa de PósGraduação em Ciência e Tecnologia Animal, Dracena, São Paulo, Brasil.

*Endereço para correspondência: lucienbissi@hotmail.com
}

\section{SUMMARY}

We evaluated the effects of increasing levels of crude glycerin in multiple supplements for grazing beef cattle on intake, nutrient digestibility, $\mathrm{pH}$, ruminal ammoniacal nitrogen, and serum glucose. Five Nellore steers (initial BW of $480 \mathrm{~kg}$ [SD 15]), grazing a tropical pasture, were used in a $5 \times 5$ Latin square design. The treatments used were control (no supplementation; only a mineral mixture ad libitum) and four levels of crude glycerin $(0,80$, $160,240 \mathrm{~g} / \mathrm{kg}$ of supplements). Supplementation type had no impact $(\mathrm{P}>0.05)$ on $\mathrm{pH}$ at 0 and $4 \mathrm{~h}$ after supplementation. Animals supplemented with different levels of crude glycerin showed higher $\mathrm{N}-\mathrm{NH}_{3}$ values $(\mathrm{P}<0.05)$ at $4 \mathrm{~h}$ after supplementation. Crude glycerin supplementation did not reduce pasture intake $(\mathrm{P}>0.05)$, increasing dry matter intake $(\mathrm{P}>0.05)$ due to increased organic matter digestibility $(\mathrm{P}>0.05)$. Supplementation of $4 \mathrm{~kg}$ /animal with crude glycerin $(240 \mathrm{~g} / \mathrm{kg}$ supplement) did not reduce pasture intake and organic matter digestibility.

Keywords: crude glycerin, nitrogen ammonia, $\mathrm{pH}$, protein

\section{RESUMO}

Objetivou-se avaliar o efeito de níveis crescentes de glicerina bruta em suplementos múltiplos, sobre consumo, digestibilidade dos nutrientes, $\mathrm{pH}$, nitrogênio amoniacal ruminal e glicose sérica. Foram utilizados cinco novilhos, Nelore (peso inicial de $480 \mathrm{~kg} \pm 15$ ), em pastejo de forragem tropical, em delineamento experimental Quadrado Latino 5X5. Os tratamentos utilizados foram controle (apenas suplementação mineral) e quatro níveis de glicerina bruta $(0,80,160,240 \mathrm{~g} / \mathrm{kg}$ de suplemento). Não houve influencia do tipo de suplementação $(\mathrm{P}>0,05)$ para $\mathrm{pH}$ no tempo zero ou quatro horas após a suplementação. Os animais suplementados com níveis de glicerina $\begin{array}{lll}\text { bruta apresentaram maior } \mathrm{N}_{-} \mathrm{NH}_{3} & (\mathrm{P}>0,05)\end{array}$ quatro horas após a suplementação, e o consumo de pasto não foi afetado $(\mathrm{P}>0,05)$, com incremento no consumo de matéria seca total $(\mathrm{P}<0,05)$, devido o aumento da digestibilidade da matéria orgânica $(\mathrm{P}<0,05)$. Os suplementos concentrados fornecidos na quantidade de $4 \mathrm{~kg}$ por animal a inclusão de glicerina bruta (240 $\mathrm{g} / \mathrm{kg}$ de suplemento) não altera o consumo de pasto, suplemento e matéria orgânica digerida.

Palavras-chave: glicerina bruta, nitrogênio amoniacal, $\mathrm{pH}$, proteína 


\section{INTRODUCTION}

Crude glycerin is a co-product of biodiesel, formed via the transesterification of fatty acids in a reaction catalyzed by sodium or potassium hydroxide and methanol (DONKIN, 2008). Rich in glycerol, a glycogenic substance, it is used as feedstuff for swines (LAMMERS et al., 2008), poultry (BOSO et al., 2013), sheep (GUNN et al., 2010), dairy cows (DONKIN, 2008), and beef cattle in growth (HALES et al., 2013, BENATI et al., 2015; BONDURANT et al., 2016) or finishing (BENEDETI et al., 2016).

The prevention and treatment of ketosis in dairy cows (SAUER et al., 1973). However, the supply of crude glycerin is increasing, driven by regulations that expand the inclusion of biodiesel fuel.

As an energy substrate, crude glycerin replaces starch to a certain amount, maintaining the production of propionate. It is therefore a viable alternative to reduce the dependence on corn, which is subject to considerable price fluctuations.

However, little is known about the interaction effects of crude glycerin on the fiber-rich diets of grazing animals (BONDURANT et al., 2016; PASCHOALOTO et al., 2016).

In this context, the objectives of this study were to assess increasing levels of crude glycerin in multiple supplements used for grazing animals. Specifically, we focused on the effects on nutrient intake and digestibility.

\section{MATERIAL AND METHODS}

The study was conducted at the sector of Nutrition of Beef Cattle in Pasture, in the experimental farm of the Faculdade de Agronomia, Medicina Veterinária e
Zootecnia - FAMEVZ, Universidade Federal de Mato Grosso - UFMT, located in the city of Santo Antônio do Leverger - MT. All experiments were performed during the rainy season over a period of 95 days.

Five Nellore bulls, with an average age of 30 months and a body weight (BW) of $480 \pm 14.8 \mathrm{~kg}$, were used in the experiment and distributed in a $5 \times 5$ Latin square design with five treatments and five periods. The treatments were as follows: only mineral supplementation (negative control), supplementation protein-energy with traditional formulation (positive control), and three additional levels of crude glycerin $(8 ; 16$ or $24 \%$ of dry matter) (Table 1).

Each experimental period lasted for 19 days, with the following phases: day 1 , forage collection; day 1 to 10, adaptation to the supplement; day 11 to 17 , application of the external indicator chromium oxide (15 g/d); day 15 to 17 , feces collection; day 18, blood and urine sampling; day 19, rumen liquid sampling ( 0 and $4 \mathrm{~h}$ after supplement supply).

To evaluate forage availability, we measured average forage height. Forage was collected to $2.5 \mathrm{~cm}$ stubble height in area delimited by two squares of $0.25 \mathrm{~m}^{2}$ in each paddock. After weighing, an aliquot was taken for dry matter evaluation and bromatological analyses and another aliquot to partition the structural components into green leaf, green stem, and senescent material.

Forage intake was evaluated via hand plucking (MORAES et al., 2005). After observing the grazing habit of the animals, we collected portions of plants similar to those taken by the animals; this procedure was carried out by one trained technician. The chromic oxide indicator was administered orally via paper capsules, using a polyethylene applicator which was introduced into the esophagus. 
Table 1. Percent composition of supplements and composition of bromatology based on dry matter

\begin{tabular}{|c|c|c|c|c|}
\hline \multirow{2}{*}{ Ingredients (g/kg) } & \multicolumn{4}{|c|}{ Inclusion level glycerin $(\mathrm{g} / \mathrm{kg})$} \\
\hline & 0 & 80 & 160 & 240 \\
\hline Crude glycerin $^{\top}$ & - & 80.0 & 160.0 & 240.0 \\
\hline Cottonseed & 250.0 & 250.0 & 250.0 & 250.0 \\
\hline Soybean hulls & 200.0 & 200.0 & 200.0 & 200.0 \\
\hline Soybean meal & 100.0 & 117.5 & 135.0 & 152.5 \\
\hline Ground corn & 470.0 & 372.5 & 275.0 & 177.5 \\
\hline Ureia: ammonia sulfate & 14.0 & 14.0 & 14.0 & 14.0 \\
\hline Mixed minerals ${ }^{2}$ & 20.0 & 20.0 & 20.0 & 20.0 \\
\hline \multicolumn{5}{|c|}{ Evaluation bromatology $(\mathrm{g} / \mathrm{kg})$} \\
\hline Dry matter & 938.9 & 935.6 & 926.5 & 923.7 \\
\hline Mineral matter & 43.9 & 49.5 & 57.4 & 62.0 \\
\hline Crude protein & 222.7 & 214.6 & 210.8 & 202.0 \\
\hline Neutral detergent insoluble fiber & 256.3 & 270.2 & 299.7 & 262.8 \\
\hline Ether extract & 87.9 & 77.6 & 84.2 & 80.3 \\
\hline $\mathrm{cpNDF}^{3}$ & 139.4 & 173.8 & 235.0 & 189.7 \\
\hline Total carbohydrates & 645.5 & 658.4 & 647.6 & 655.6 \\
\hline Non-fiber carbohydrates & 538.4 & 516.7 & 444.8 & 498.2 \\
\hline
\end{tabular}

${ }^{\mathrm{I}}$ Composition crude glycerin: dry matter 915 g/kg; Glycerol 831 g/kg, CP: absent; Ash: $60 \mathrm{~g} / \mathrm{kg}$; EE: 16 $\mathrm{g} / \mathrm{kg}$; Methanol: $2 \mathrm{~g} / \mathrm{kg}$; Sodium: $5 \mathrm{~g} / \mathrm{kg}$.

${ }^{2}$ Commercial mineral supplement: Level of guarantee: calcium $198 \mathrm{~g}$; phosphorus $87 \mathrm{~g}$; sodium $97.6 \mathrm{~g}$; magnesium $5.1 \mathrm{~g}$; sulfur $12 \mathrm{~g}$; iodine $17.7 \mathrm{mg}$; ferric $280 \mathrm{mg}$; selenium $18 \mathrm{mg}$; cobalt $80 \mathrm{mg}$; manganese $527 \mathrm{mg}$; flour $870 \mathrm{mg}$; copper $1.250 \mathrm{mg}$, and zinc $3.500 \mathrm{mg}$.

${ }^{3}$ Neutral detergent insoluble fiber corrected for ash and protein.

Fecal samples were collected on d 15, 16 , and 17 of each period, directly from the rectum, at 16:00, 12:00, and 08:00 $\mathrm{h}$ on the first, second, and third days of collection, respectively.

The blood samples were collected from the coccygeal vein, $4 \mathrm{~h}$ after supplementation supply. An aliquot of 5 $\mathrm{mL}$ was added to fluoride EDTA to prevent coagulation, centrifuged immediately for 10 minutes at 3,000 rpm, and analyzed for glucose via an enzymatic colorimetric method, using a commercial kit (Glicose PP Cat 434 Analisa $^{\mathbb{B}}$ ) with spectrophotometer reading.

Ruminal fluid was collected at 0 and 4 hours after supplementation to determine $\mathrm{pH}$ and ammonia; samples were obtained via an esophageal tube. The tube was directed towards the glottis and introduced into the esophagus until reaching the reticulum- rumen; rumen liquid was collected via negative pressure and the first portion was discarded to avoid contamination with saliva. The ruminal sample was filtered three times through cheese cloth and the $\mathrm{pH}$ was measured immediately after collection, using a digital $\mathrm{pH}$ meter.

For the determination of ammonia, a 50 $\mathrm{mL}$ aliquot of ruminal liquid was added to $1 \mathrm{~mL}$ of 1: 1 sulfuric acid and frozen at $-20{ }^{\circ} \mathrm{C}$, for further analysis. was Ammonia was determined by the microKjeldahl system, without acid digest, via distillation with potassium hydroxide $(\mathrm{KOH}) 2 \mathrm{~N}$, according to Detmann et al. (2012) (method INCTCA no. N-006/1).

Samples of the forage (total collected and hand plucked), the concentrate food, and the feces (daily each animal, each period) were dried via forced ventilation $\left(55^{\circ} \mathrm{C}\right.$ for $\left.72 \mathrm{~h}\right)$ and ground 
in a Wiley mill (Thomas Scientific, Swedesboro, NJ) to pass through a 1$\mathrm{mm}$ screen for chemical analyses and through a $2 \mathrm{~mm}$ screen for in-situ incubation (determination of iNDF). The dry daily feces samples each animal, each period, it was compost sample, after chemical analyses.

Forage, concentrate, and feces samples were analyzed for dry matter (DM, method $\mathrm{N}^{\mathrm{O}}$ 934.01), organic matter $\left(\mathrm{OM}\right.$, method $\left.\mathrm{N}^{\mathrm{O}} 942.05\right)$, crude protein (CP, method $\mathrm{N}^{\mathrm{O}}$ 954.01), and ether extract (EE, method $\mathrm{N}^{0}$ 920.39) according to the AOAC (1990). To analyze neutral detergent fiber (NDF), the samples were treated with thermostable alfa-amylase without the use of sodium sulfite, corrected for ash residue (MERTENS, 2002) and residue of nitrogen compounds (LICITRA et al., 1996). Determination of NDF was performed using $5 \times 5 \mathrm{~cm}$ TNT (tissue-non-tissue) bags, containing an average of $14 \mathrm{mg}$ of $\mathrm{DM} / \mathrm{cm}^{2}$ of tissue and $100 \mathrm{~mL}$ of neutral detergent/g of air-dried sample. The concentration of iNDF in food and feces was obtained after incubation for a period of $240 \mathrm{~h}$ (CASALI et al., 2008).

The non-fibrous carbohydrate contents corrected for ash and protein $\left(\mathrm{NFC}_{\mathrm{cp}}\right)$ were calculated as proposed by Hall (2000) and adapted as follows: $\mathrm{NFC}_{\mathrm{cp}}=$ $100-[(\mathrm{CP}-\mathrm{CP}$ ureia + ureia in the diet $)$ $\left.+\mathrm{NDF}_{\mathrm{cp}}+\mathrm{EE}+\mathrm{Ash}\right]$. Total digestible nutrients (TDN) were calculated as described by Weiss (1999), with adaptation, using the following equation: $\mathrm{TDN}(\mathrm{g} / \mathrm{kg})=\mathrm{DCP}+$ cpDNDF + cpDNFCD + 2.25 DEE, where DCP is the digestible crude protein, cpDNDF is the digestible neutral detergent fiber, cpDNFC are the digestible non-fiber carbohydrates, and DEE is the digestible ether extract.

Feces samples containing oxide chromium were analyzed to quantify the chromium content via atomic absorption spectrophotometry, according to the methodology described by Willians et al. (1962).

The excretion of fecal dry matter was estimated $(\mathrm{g} / \mathrm{d})$ by the ratio of the quantity supplied from the external indicator (oxide chromium) and the feces concentration $(\mathrm{g} / \mathrm{kg}$, Burns et al., 1994). To obtain estimates of dry matter intake (DMI), indigestible neutral detergent fiber (iNDF) was used as an internal indicator, applying the following equation:

$$
\mathrm{DMI}=\left[\frac{(\mathrm{FE} \mathrm{X} \mathrm{FIC})-\mathrm{IS}}{\mathrm{ICFO}}\right]+\text { DMIS }
$$

where DMI is the dry matter intake, FF is the fecal excretion $(\mathrm{kg} / \mathrm{d})$, FIC iNDF is the indicator concentration in the feces $(\mathrm{g} / \mathrm{kg})$, IS iNDF is the indicator present in the supplement $(\mathrm{kg} / \mathrm{d})$, ICFO iNDF is the indicator concentration in the forage $(\mathrm{g} / \mathrm{kg})$, and DMIS is the dry matter intake of the supplement $(\mathrm{kg} / \mathrm{d})$.

The data were analyzed in a $5 \times 5$ Latin square experimental design, using a mixed model (Littell et al., 1998) in PROC MIXED SAS 9.1.

$$
\mathrm{Y}_{\mathrm{ij}(\mathrm{k})}=\mu+\mathrm{A}_{\mathrm{j}}+\mathrm{P}_{\mathrm{j}}+\mathrm{T}_{(\mathrm{k})}+\mathrm{e}_{\mathrm{ij}(\mathrm{k})}
$$

in which where $Y_{i j(k)}$ is the observation for animal $i$ in the period $j$, submitted to treatment $\mathrm{k}, \mu$ is the overall average, $\mathrm{T}_{(\mathrm{k})}$ is the fixed effect of treatment $\mathrm{k}$, as $\mathrm{k}=$ $1,2,3,4$, and $5, \mathrm{~A}_{\mathrm{i}}$ is the random effect of animal $\mathrm{i}$, as $\mathrm{i}=1,2,3,4,3,5, \mathrm{P}_{\mathrm{k}}$ is the random effect of period $\mathrm{j}$, as $\mathrm{j}=1,2$, 3,4 , and $5 ; \mathrm{e}_{\mathrm{ij}(\mathrm{k})}$ is the random error, associated with each observation, assumption NID $\left(0 ; \sigma^{2}\right)$.

The effects of treatments were partitioned into four orthogonal contrasts: 1 negative control versus supplementation protein-energy (SM vs supplementation concentrate); 
2 positive control versus $8 \%$ inclusion of crude glycerin in DM of supplement (Glyc 0 vs Glyc 8); 3 positive control versus $16 \%$ inclusion of crude glycerin in DM of supplement (Glyc 0 vs Glyc 16); 4 positive control versus $24 \%$ inclusion of crude glycerin in DM of supplement (Glyc 0 vs Glyc 24). A level of 0.05 probability was adopted for type I error. The results are presented as least squares means.

Forage data (quantitative and qualitative) were submitted to variance analysis and Scott-Knott's media pool test; we selected the analysis of conglomerates rather than multiple comparisons to avoid ambiguity in the interpretation of forage results, adopting a probability level of 0.05 for Type I error.

\section{RESULTS AND DISCUSSION}

Average capacity was $5.30 \mathrm{UA} \mathrm{ha}^{-1}$, which is considered relatively high for continuous grazing management systems. Dry matter availability in green leaves decreased $(\mathrm{P}<0.01)$ and dry leaf and stem mass increased $(\mathrm{P}<0.01)$ with high grazing pressure. In contrast, dry matter availability did not change significantly $(\mathrm{P}>0.05)$ throughout the experimental period (Table 2).

Dry matter availability is an important factor influencing food intake and animal performance. According to a previous study, the threshold level is $2.000 \mathrm{~kg} \mathrm{ha}^{-1}$, ensuring voluntary intake of grazing animals (MINSON, 1990).

Table 2. Dry matter availability (kg MS ha-1) and bromatological components

\begin{tabular}{|c|c|c|c|c|c|c|c|}
\hline \multirow{2}{*}{ Item $^{2}$} & \multicolumn{5}{|c|}{ Period } & \multirow{2}{*}{$\mathrm{p}-$ Value $e^{l}$} & \multirow{2}{*}{$\mathrm{CV}(\%)$} \\
\hline & 1 & 2 & 3 & 4 & 5 & & \\
\hline $\mathrm{DM}$ & 5,127 & 7,015 & 9,261 & 6,808 & 7,504 & 0.13 & 33.09 \\
\hline pdDM & 4,754 & 6,410 & 8,492 & 6,292 & 5,552 & 0.14 & 32.86 \\
\hline GL & $2,538^{\mathrm{a}}$ & $2,599^{\mathrm{b}}$ & $2,819^{\mathrm{c}}$ & $1,762^{\mathrm{c}}$ & $1,601^{\mathrm{c}}$ & 0.01 & 21.01 \\
\hline DL & $384^{\mathrm{b}}$ & $906^{\mathrm{a}}$ & $1,369^{\mathrm{a}}$ & $1,153^{\mathrm{a}}$ & $1,432^{\mathrm{a}}$ & 0.01 & 35.95 \\
\hline GS & 2,203 & 3,433 & 4,290 & 2,628 & 2,317 & 0.06 & 40.75 \\
\hline DS & $0.00^{\mathrm{d}}$ & $75.52^{\mathrm{d}}$ & $781^{\mathrm{c}}$ & $1,264^{\mathrm{c}}$ & $2,153^{\mathrm{a}}$ & 0.01 & 49.25 \\
\hline
\end{tabular}

${ }^{1}$ Values followed by the same lowercase letter within one line are not significantly different at a probability level of 5\% by Scott-Knott's test.

${ }^{2}$ Dry matter (DM); Dry matter potentially digestible (pdDM); Green leaf (GL); Dry leaf (DL); Green stem (GS); Dry stem (DS).

However, tropical forage shows a high variability in dry matter availability (SILVA et al., 2009), making it necessary to assess the proportion of plant constituents as the reduction in leaf availability could negatively influence forage intake (GONTIJO NETO et al., 2006). High dry matter availability increases the selection of forage and thus mitigates the negative effects of decreasing leaf biomass and increasing senescent matter mass.

The measurement of forage availability is crucial since the regulation of intake may be by ruminal filling, in function of the lower rate of passage of fibrous compounds (ALLEN, 1996). Therefore, the evaluation of potentially digestible dry matter is important for the evaluation of beef cattle production systems that aim to maximize forage use. 
Potentially digestible dry matter availability did not change throughout the experimental period, corroborating with greater possibility of selection, in function high of forage availability.

The proportion of senescent material in the dry matter increased $(\mathrm{P}<0.01)$, while cpNDF, iNDF, crude protein, NFC, and ether extract decreased $(\mathrm{P}<0.01)$ over time, with a reduction in cellular contents and an increase in structural components as the plants matured (LIMA et al., 2012), leading to increased dry plant mass (Table 3 ).

Table 3. Bromatological composition $(\mathrm{g} / \mathrm{kg})$ of the pasture grass Brachiaria Brizantha, collected to evaluate total availability

\begin{tabular}{lccccccc}
\hline \multirow{2}{*}{ Composition 2 } & \multicolumn{5}{c}{ Period } & \multirow{2}{*}{-Value1 } & CV $(\%)$ \\
\cline { 2 - 6 } & 1 & 2 & 3 & 4 & 5 & & \\
\hline DM & $236.9^{\mathrm{c}}$ & $264.3 \mathrm{c}$ & $338.3^{\mathrm{b}}$ & $501.3^{\mathrm{a}}$ & $447.6^{\mathrm{a}}$ & $<0.001$ & 15.65 \\
MM & $75.1^{\mathrm{a}}$ & $61.0^{\mathrm{b}}$ & $64.5^{\mathrm{b}}$ & $68.6^{\mathrm{a}}$ & $70.9^{\mathrm{a}}$ & 0.007 & 8.27 \\
OM & $924.8^{\mathrm{b}}$ & $938.9^{\mathrm{a}}$ & $935.4^{\mathrm{a}}$ & $931.3^{\mathrm{b}}$ & $929.0^{\mathrm{b}}$ & 0.007 & 0.60 \\
CP & $62.0^{\mathrm{a}}$ & $38.7^{\mathrm{b}}$ & $39.0^{\mathrm{b}}$ & $41.0^{\mathrm{b}}$ & $49.4^{\mathrm{b}}$ & 0.006 & 22.02 \\
cpNDF & $661.3^{\mathrm{b}}$ & $710.2^{\mathrm{a}}$ & $698.2^{\mathrm{a}}$ & $719.7^{\mathrm{a}}$ & $679.2^{\mathrm{b}}$ & 0.001 & 2.86 \\
iNDF & $167.8^{\mathrm{c}}$ & $183.9^{\mathrm{c}}$ & $244.4^{\mathrm{b}}$ & $294.9^{\mathrm{a}}$ & $288.9^{\mathrm{a}}$ & $<0.001$ & 8.23 \\
NFC & 219.4 & 209.3 & 216.9 & 191.4 & 231.3 & 0.11 & 8.78 \\
EE & $14.2^{\mathrm{a}}$ & $12.8^{\mathrm{a}}$ & $13.4^{\mathrm{a}}$ & $11.3^{\mathrm{b}}$ & $11.3^{\mathrm{b}}$ & $<0.001$ & 8.54
\end{tabular}

${ }^{1}$ Values followed by the same lowercase letter within one line are not significantly different at a probability level of $5 \%$ by Scott-Knott's test.

${ }^{2}$ Dry matter (MS); Mineral matter (MM); Organic matter (OM); Crude protein (CP); Neutral detergent insoluble fiber corrected for ash and protein $\left({ }_{\mathrm{cp}} \mathrm{NDF}\right)$; Indigestible neutral detergent insoluble fiber $\left.{ }_{\mathrm{i}} \mathrm{NDF}\right)$; Non-fiber carbohydrates (NFC); Ether extract (EE).

However, crude protein levels of the hand-plucked material did not change $(\mathrm{P}>0.05)$ over time, indicating that the animals selected the forage to mitigate seasonal differences. A crude protein level of $7 \%$ is considered the threshold for the maintenance of microbial growth and the efficient use of fibrous substrates (Table 4).

The type of supplementation had no effect on $\mathrm{pH}(\mathrm{P}>0.05)$ at 0 or 4 hours after supplementation (Table 5), which leads us to infer that the capacity for the removal of volatile fatty acids and tamponade by salivation, was sufficient to maintain a ruminal $\mathrm{pH}$ higher than 6.0 , which is the critical value for the inhibition of cellulose-fermenting bacteria and the reduction of microbial protein synthesis (VALADARES FILHO \& PINA, 2006).
Although there are reports that the replacement for starch by glycerol can reduce the $\mathrm{pH}$, this resulted in a faster fermentation with a higher rate of VFA production (MACH et al., 2009; RAMOS \& KERLEY, 2012). However, the forage represents a large part of the diet, which favors ruminal buffering. Thus, glycerin had no effect on the ruminal $\mathrm{pH}$, which has also been observed by Botini et al. (2015) when replacing up to $100 \%$ of maize by crude glycerin, offering $4 \mathrm{~kg}$ in the supplement/animal/day. Similar results were observed by Lage et al. (2017), who evaluated the inclusion of $10 \%$ crude glycerin in fiber-based diets.

Time zero, didn't effect of supplementation or addition of crude glycerin for concentration of ruminal ammonia nitrogen $(\mathrm{P}<0.05$; Table 5). 
Table 4. Bromatological composition $(\mathrm{g} / \mathrm{kg})$ of the pasture grass Brachiaria Brizantha, collected via hand plucking.

\begin{tabular}{|c|c|c|c|c|c|c|c|}
\hline \multirow{2}{*}{ Composition } & \multicolumn{5}{|c|}{ Period } & \multirow{2}{*}{$\mathrm{p}-$ Value $^{l}$} & \multirow{2}{*}{ CV $(\%)$} \\
\hline & 1 & 2 & 3 & 4 & 5 & & \\
\hline DM & $279.1^{b}$ & $288.8^{\mathrm{b}}$ & $269.7^{b}$ & $306.0^{b}$ & $358.7^{\mathrm{a}}$ & 0.041 & 11.28 \\
\hline MM & $66.4^{\mathrm{b}}$ & $64.3^{b}$ & $65.8^{\mathrm{b}}$ & $76.8^{\mathrm{a}}$ & $69.7^{\mathrm{b}}$ & 0.008 & 6.54 \\
\hline $\mathrm{OM}$ & $935.5^{\mathrm{a}}$ & $936.8^{\mathrm{a}}$ & $931.4^{\mathrm{a}}$ & $923.1^{\mathrm{b}}$ & $930.2^{\mathrm{a}}$ & 0.008 & 0.48 \\
\hline $\mathrm{CP}$ & 98.2 & 98.2 & 102.6 & 98.6 & 101.1 & 0.731 & 6.29 \\
\hline cpNDF & $572.4^{\mathrm{b}}$ & $603.5^{\mathrm{a}}$ & $545.1^{\mathrm{c}}$ & $539.8^{c}$ & $499.7^{\mathrm{d}}$ & 0.001 & 2.96 \\
\hline iNDF & $105.1^{\mathrm{a}}$ & $101.7^{\mathrm{a}}$ & $99.1^{\mathrm{a}}$ & $105.6^{\mathrm{a}}$ & $87.9^{\mathrm{b}}$ & 0.006 & 7.30 \\
\hline NFC & $270.0^{\mathrm{c}}$ & $243.6^{\mathrm{d}}$ & $295.5^{\mathrm{b}}$ & $293.5^{\mathrm{b}}$ & $336.1^{\mathrm{a}}$ & 0.001 & 5.54 \\
\hline EE & $26.9^{\mathrm{a}}$ & $23.5^{\mathrm{b}}$ & $20.2^{\mathrm{c}}$ & $23.3^{\mathrm{b}}$ & $25.3^{\mathrm{a}}$ & 0.001 & 7.68 \\
\hline
\end{tabular}

${ }^{1}$ Values followed by the same lowercase letter within one line are not significantly different at a probability level of $5 \%$ by Scott-Knott's test.

${ }^{2}$ Dry matter (MS); Mineral matter (MM); Organic matter (OM); Crude protein (CP); Neutral detergent insoluble fiber corrected for ash and protein $\left({ }_{\mathrm{cp}} \mathrm{NDF}\right)$; Indigestible neutral detergent insoluble fiber ${ }_{\mathrm{i}} \mathrm{NDF}$ ); Non-fiber carbohydrates (NFC); Ether extract (EE).

Table 5. $\mathrm{pH}$ and concentration of ruminal ammonia nitrogen (N-NH3, mg/dl) at 0 and $4 \mathrm{~h}$ after supplementation

\begin{tabular}{lcccccccccc}
\hline \multirow{2}{*}{ Item } & \multicolumn{4}{c}{ Inclusion of glycerin in supplement } & \multicolumn{3}{c}{ Orthogonal contrasts $^{1}$} & \multirow{2}{*}{ CV } \\
\cline { 2 - 10 } & $\mathrm{SM}$ & $0 \%$ & $8 \%$ & $16 \%$ & $24 \%$ & 1 & 2 & 3 & 4 & \\
\hline $\mathrm{pH} 0$ & 6.85 & 6.85 & 6.80 & 6.80 & 6.86 & 0.59 & 0.81 & 0.33 & 0.28 & 2.09 \\
$\mathrm{pH} 4$ & 6.68 & 6.61 & 6.51 & 6.53 & 6.65 & 0.18 & 0.65 & 0.33 & 0.44 & 2.67 \\
$\mathrm{NH}_{3} 0$ & 3.72 & 6.08 & 5.68 & 5.03 & 4.40 & 0.09 & 0.86 & 0.73 & 0.27 & 41.77 \\
$\mathrm{NH}_{3} 4$ & 5.46 & 15.64 & 11.57 & 12.25 & 10.50 & 0.00 & 0.16 & 0.23 & 0.06 & 42.39 \\
$\mathrm{BG}^{2}$ & 75.50 & 75.80 & 77.00 & 75.75 & 73.20 & 0.18 & 0.19 & 0.29 & 0.06 & 6.44 \\
\hline
\end{tabular}

${ }^{1}$ Orthogonal contrasts 1: SM vs supplementation concentrate; 2: Glyc 0 vs Glyc 8; 3: Glyc 0 vs Glyc 16; 4: Glyc 0 vs Glyc 24.

${ }^{2} \mathrm{BG}=$ blood glucose $(\mathrm{mg} / \mathrm{dl})$.

Bohnert et al. (2002) state that ruminants can conserve $\mathrm{N}$ over longer periods in the form of urea, possibly through changes in the permeability of the gastrointestinal tract or the regulation of renal excretion, maintaining the supply of $\mathrm{N}$ between supplementation intervals.

After protein-energy supplementation, the concentration of ammoniacal nitrogen increased by 10 to $20 \mathrm{mg}$ of $\mathrm{N}-\mathrm{NH}_{3} / \mathrm{dL}$ of ruminal liquid, which is the ideal $\mathrm{N}-\mathrm{NH}_{3}$ concentration for the synthesis of microbial crude protein in tropical regions (LENG, 1990). In the negative control, offering only mineral supplementation, the mean value of the experimental periods was below $5 \mathrm{mg}$ of $\mathrm{N}-\mathrm{NH}_{3} / \mathrm{dL}$ of ruminal liquid, below the critical value for the synthesis of microbial protein in animals on forage-based diets (LENG, 1990; DETMANN et al., 2009).

In previous studies, Abo El-nor et al. (2010), Peripolli et al. (2014), and Botini et al. (2015) evaluated the replacement of corn by increasing levels of crude glycerin and observed no effects on ruminal $\mathrm{NH}_{3}$ concentrations. Serum blood glucose was not affected by protein-energy supplementation or the level of crude glycerin inclusion in supplements. maximum ruminal fermentation, with a higher production 
of volatile fatty acids by the supply of supplemental nutrients, could support higher serum glucose levels in relation to the supply of minerals. However, the additionally produced propionate, which is the main precursor of glucose in ruminants, was oxidized in the liver for energy production, without the occurrence of gluconeogenesis (KOZLOSKI, 2011). Therefore, the concentrated supplementation or the increase in the level of glycerol was sufficient to increase the concentration of hexose in the blood.
Protein-energy supplementation did not affect $(\mathrm{P}>0.05)$ pasture intake, but increased $(\mathrm{P}<0.05)$ dry matter and total digestible nutrient intake, indicating an additive effect on forage intake (Table 6). Attributing to the highest contribution of nutrients to ruminal microbiota, with organic matter digestible increase $(\mathrm{P}<0.05)$ (Table 6) and reduction effect ruminal repletion of dietary with supplementation proteinenergy (ALLEN, 1996).

Table 6. Intake and digestibility of mineral or protein-energy supplementation with crude glycerin

\begin{tabular}{|c|c|c|c|c|c|c|c|c|c|c|}
\hline \multirow{2}{*}{ Variable } & \multicolumn{5}{|c|}{ Inclusion of glycerin in the supplement } & \multicolumn{4}{|c|}{ Orthogonal contrast $^{1}$} & \multirow{2}{*}{$\mathrm{CV}$} \\
\hline & Salt & $0 \%$ & $8 \%$ & $16 \%$ & $24 \%$ & 1 & 2 & 3 & 4 & \\
\hline \multicolumn{11}{|c|}{ Intake (kg/day) } \\
\hline Forage & 7.76 & 5.67 & 7.14 & 7.71 & 7.46 & 0.51 & 0.33 & 0.18 & 0.24 & 30.06 \\
\hline Supplement & - & 3.76 & 3.74 & 3.71 & 3.69 & - & - & - & - & 51.03 \\
\hline Dry matter & 7.76 & 9.43 & 10.88 & 11.42 & 11.15 & 0.02 & 0.33 & 0.19 & 0.25 & 24.07 \\
\hline Organic matter & 7.23 & 8.46 & 9.89 & 9.34 & 9.28 & 0.01 & 0.23 & 0.19 & 0.40 & 18.28 \\
\hline Ether extract & 0.18 & 0.46 & 0.47 & 0.48 & 0.42 & 0.01 & 0.77 & 0.57 & 0.44 & 33.00 \\
\hline Crude protein & 0.756 & 1.36 & 1.54 & 1.56 & 1.48 & 0.01 & 0.23 & 0.19 & 0.40 & 27.24 \\
\hline $\begin{array}{l}\text { Neutral detergent } \\
\text { insoluble fiber }\end{array}$ & 4.85 & 4.45 & 5.45 & 5.73 & 5.75 & 0.50 & 0.29 & 0.18 & 0.17 & 27.31 \\
\hline $\begin{array}{l}\text { Non-fiber } \\
\text { carbohydrates }\end{array}$ & 1.96 & 3.39 & 3.52 & 3.50 & 3.62 & 0.01 & 0.71 & 0.76 & 0.52 & 24.71 \\
\hline $\begin{array}{l}\text { Total digestible } \\
\text { nutrients }\end{array}$ & 5.10 & 7.17 & 8.12 & 8.35 & 8.18 & 0.01 & 0.34 & 0.24 & 0.31 & 24.54 \\
\hline \multicolumn{11}{|c|}{ Intake $(\% \mathrm{PC})$} \\
\hline Dry matter & 1.2 & 1.6 & 1.6 & 1.8 & 1.8 & 0.09 & 1 & 0.57 & 0.57 & 31.25 \\
\hline \multicolumn{11}{|c|}{ Digestibility $(\mathrm{g} / \mathrm{kg})$} \\
\hline Dry matter & 637.0 & 691.3 & 694.8 & 707.9 & 698.0 & 0.00 & 0.60 & 0.36 & 0.33 & 5.12 \\
\hline Organic matter & 684.4 & 702.6 & 706.3 & 735.8 & 709.3 & 0.03 & 0.80 & 0.75 & 0.85 & 7.56 \\
\hline Ether extract & 272.0 & 832.0 & 760.0 & 806.0 & 80.75 & 0.01 & 0.01 & 0.23 & 0.30 & 33.03 \\
\hline Crude protein & 636.0 & 716.0 & 724.0 & 726.0 & 71.00 & 0.01 & 0.80 & 0.75 & 0.85 & 8.30 \\
\hline $\begin{array}{l}\text { Neutral detergent } \\
\text { insoluble fiber }\end{array}$ & 750.0 & 732.0 & 746.0 & 760.0 & 75.60 & 0.91 & 0.46 & 0.15 & 0.21 & 3.84 \\
\hline $\begin{array}{l}\text { Non-fiber } \\
\text { carbohydrates }\end{array}$ & 634.0 & 777.0 & 792.0 & 742.0 & 74.00 & 0.00 & 0.60 & 0.36 & 0.33 & 9.89 \\
\hline $\begin{array}{l}\text { Total digestible } \\
\text { nutrients }\end{array}$ & 662.0 & 762.0 & 750.0 & 732.0 & 73.60 & 0.01 & 0.65 & 0.27 & 0.34 & 6.96 \\
\hline
\end{tabular}


Silva et al. (2016) and Lage et al. (2017) reported that the caloric and rapid increase in ruminal fermentation, with propionate and butyrate production, it was could the key point for studies in which there is observed intake reduction, with hepatic oxidation increase and high use of this VFA to obtain energy in the liver, occurs regulation chemostatic of intake (ALLEN et al., 2009). However, the amounts offered in this study were not sufficient for this effect.

Diets with crude protein levels below $12 \%$ (in basic dry matter) for beef cattle decrease DMI, food efficiency, and nitrogen retention, mainly because of the reduction in the ruminal fermentation capacity due to a lack of $\mathrm{N}$ for microbial growth (COLE et al., 2006). Thus, additional $\mathrm{CP}$ intake is important to increase ruminal fermentation, resulting in higher dry matter digestibility, as he supply of mineral supplementation resulted in a diet with sub-optimal levels of CP (9\% of CP; $0.756 \mathrm{~kg}$ of $\mathrm{CP} / 7.76 \mathrm{~kg}$ of $\mathrm{DM})$. Diets including supplemented levels of $13.8 \%$ of $\mathrm{CP}$ $(1.485 \mathrm{~kg}$ of $\mathrm{CP} / 10.72 \mathrm{~kg}$ of $\mathrm{DM})$ support high weight gain rates (VALADARES FILHO et al., 2010).

The supplementation, ether extract apparent digestible increase in function great $(\mathrm{P}<0.001) \mathrm{EE}$ intake, which reduced the contribution of endogenous fecal EE (VAN SOEST, 1994), corroborating also the increase in the energy intake of the animals that received protein-energy supplementation.

Our hypothesis that crude glycerin can replace part of the corn in the supplement, without impairing nutritional and ruminal parameters, was confirmed. However, this was only the case for a crude glycerin intake of up to $0.96 \mathrm{~kg}$, which represented about $10 \%$ of the animal's daily dry matter intake.
In concentrated supplements, with a crude glycerin inclusion of $24 \%$, pasture and supplement intake or digestible organic matter are not reduced. Protein-energy supplementation is therefore fundamental to maximize dry matter consumption and to increase nutrient use.

\section{REFERENCES}

ALLEN, M.S. Physical constraints on voluntary intake of forages by ruminants. Journal of Animal Science, v.74, p.3063-3075, 1996.

ALLEN, M.S.; BRADFORD, B.J.; OBAM, M. BOARD-INVITED

REVIEW: The hepatic oxidation theory of the control of feed intake and its application to ruminants. Journal of Animal Science, v.87, p.3317-3334, 2009.

ASSOCIATION of OFFICIAL ANALYTICAL CHEMISTS - AOAC. Official Methods of Analysis. 15th ed. Arlington, VA: Association of Official Analytical Chemists, 1990.

BENEDETI, P.D.B.; PAULINO, P.V.R.; MARCONDES, M.I.; MACIEL, I.F.S.; SILVA, M.C.; FACIOLA, A.P. Partial replacement of ground corn with glycerol in beef cattle diets: intake, digestibility, performance, and carcass characteristics.

Plos One, p. 1-14, 2016.

BOHNERT, D.W.; SCHAUER, C.S.; DELCURTO, T. Influence of rumen protein degradability and supplementation frequency on performance and nitrogen use in ruminants consuming low-quality forage: Cow performance and efficiency of nitrogen use in wethers. Journal of Animal Science, v.80, n.6, p.1629-1637, 2002. 
BONDURANT, R.G.; HARDING, J.L.; JOLLY-BREITHAUPT, M.; MACDONALD, J.; MCCAIN, A.R. Effect of crude glycerin concentration on forage digestion parameters in beef calves. Nebraska Beef Cattle Reports, v.860, p.38-43, 2016.

BOSO, K.M.O.; MURAKAMI, A.E.; DUARTE, C.R.A.; NASCIMENTO, G.R.; MATOMOTO-PINTRO, P.T.; OSPINA-ROJAS, I.C. Fatty Acid Profile, Performance and Quality of Eggs from Laying Hens Fed with Crude Vegetable Glycerine. International Journal of Poultry Science, v.12, n.6, p.341-347, 2013.

BOTINI, L.A.; MORAES, K.A.K.; MORAES, E.H.B.K.; PINA, D.S.; PAULA. D.C.; HOFFMANN, A.; STINGUEL, H.; SOCREPPA, L.M.; MENESES, D.M. Glicerina bruta em suplementos para bovinos de corte a pasto no período seco. Pesquisa Agropecuária Brasileira, v.50, n.3, p.242-249, 2015.

BURNS, J.C.; POND, K.R.; FISHER, D.S. Measurement of Forage Intake. In: FAHEY JUNIOR, G.C. (Ed.) Forage quality, evaluation, and utilization. Winsconsin: American Society of Agronomy, 1994. p. 494-532.

CASALI, A.O.; DETMANN, E.; VALADARES FILHO, S. de C.; PEREIRA, J.C.; HERINQUES, L.T.; FREITAS, S.G. de F.; PAULINO, M.F. Influência do tempo de incubação e do tamanho de partículas sobre os teores de compostos indigestíveis em alimentos e fezes bovinas obtidos por procedimentos in situ. Revista

Brasileira de Zootecnia, v.37, n.2, p.335-342, 2008.
COLE, N.A.; DEFOOR, P.J.; GALYEAN, M.L.; DUFF, G.C.; GLEGHON, J.F. Effects of phase-feeding of crude protein on performance, carcass characteristics, serum urea nitrogen concentrations, and manure nitrogen of finishing beef steers. Journal of Animal Science, v.84, p.3421-3432, 2006.

DETMANN, E.; SOUZA, M.A.; VALADARES FILHO, S.C.; QUEIROZ, A.C.; BERCHIELLI, T.T.; SALIBA, E.O.S. Métodos para análise de alimentos. Instituto Nacional de Ciência e Tecnologia em Ciência Animal. Visconde do Rio Branco: Suprema, 2012. $214 \mathrm{p}$.

DETMANN, E.; PAULINO, M.F.; MANTOVANI, H.C.; VALADARES FILHO, S. DE C.; SAMPAIO, C.B.; SOUZA, M.A. DE; LAZZARINI, Í; DETMANN, K.S.C. Parameterization of ruminal fibre degradation in low quality tropical forage using Michaelis Menten kinetics. Livestock Science, v.126, p.136-146, 2009.

DONKIN, S.S. Glycerol from biodiesel production: the new corn for dairy cattle. Revista Brasileira de Zootecnia, v.37, n. spe, p.280-286, 2008.

EL-NOR, S.A.; ABUGHAZALEH, A.A.; POTU, R.B.; KHATTAB, M.S.A. Effects of differing levels of glycerol on rumen fermentation and bacteria, Animal Feed Science and Technology, v.162, p.99$105,2010$.

GONTIJO NETO, M.M.; EUCLIDES, V.P.B.; NASCIMENTO JÚNIOR, D.; MIRANDA, L.F.; FONSECA, D.M.; OLIVERIA, M.P. Consumo e tempo diário de pastejo por novilhos Nelore em pastagem de capim-tanzânia sob diferentes ofertas de forragem. Revista Brasileira de Zootecnia, v.35, n.1, p. 6066, 2006. 
GUNN, P.J; NEARY, M.K;

LEMENAGER, R.P, LAKE, S.L.

Effects of crude glycerin on

performance and carcass characteristics

of finishing wether lambs, Journal of

Animal Science, v.88, p.1871-1876,

2010.

HALES, K.E.; KRAICH, K.J.;

BONDURANT, R.G.; MEYER, B.E.;

LUEBBE, M.K.; BROWN, M.S.;

COLE, N.A.; MACDONALD, J.C.

Effects of glycerin on receiving

performance and health status of beef steers and nutrient digestibility and rumen fermentation characteristics of growing steers. Journal of Animal Science, v.91, p.4277-4289, 2013.

HALL, M.B. Neutral detergentsoluble carbohydrates: nutritional relevance and analysis, a laboratory manual. Gainesville: University of Florida, 2000. 42p. (Extension Bulletin, 339).

\section{KOZLOSKI, G.V. Bioquímica dos}

Ruminantes. 3.ed. ver. e amp. Santa Maria, RS: UFMS, 2011. 216 p.

LAGE, J.F.; VITO, E.S.; REIS, R.A.; DELEVATTI, L.M.; PIERRE, N.S.; BERCHIELLI, T.T. Ruminal fermentation of Nellore steers fed crude glycerine replacing starch vs. fibrebased energy ingredient in low or high concentrate diets. Acta Scientiarum. Animal Sciences, v.39, n.1, p.57-64, 2017.

LAMMERS, P.; KERR, B.J.; HONEYMAN, M.; STALDER, K.; DOZIER, W.A.; WEBER, T.E.; KIDD, M.T.; BREGENDAHL, K. Nitrogencorrected apparent metabolizable energy value of crude glycerol for laying hens. Journal of Animal Science, v.87, n.1, p.104-107, 2008.
LENG, R.A. Factors affecting the utilization of "poorquality" forages by ruminants particularly under tropical conditions. Nutrition Research Review, v.3, n.3, p.277-303, 1990.

LICITRA, G.; HERNANDEZ, T.M.; VAN SOEST, P.J. Standardization of procedures for nitrogen fractionation of ruminant feeds. Animal Feed Science and Technology, v.57, p.347-358, 1996.

LIMA, J.B.M.P.; RODRÍGUES, N.M.; MARTHA JÚNIOR, G.B.; GUIMARÃES JÚNIOR, R.; VILELA, L.; GRAÇA, D.S.; SALIBA, E.O.S. Suplementação de novilhos Nelore sob pastejo, no período de transição águasseca. Arquivo Brasileiro Medicina Veterinária e Zootecnia, v.64, n.4, p.943-952, 2012.

MACH, N.; BACH, A.; DEVANT, M. Effects of crude glycerin supplementation on performance and meat quality of Holstein bulls fed high-concentrate diets. Journal of Animal Science, v.87, p.632638, 2009.

MERTENS, D.R. Gravimetric determination of amylase-treated neutral detergent fiber in feeds with refluxing in beaker or crucibles: collaborative study. Journal of AOAC International, v.85, p.1217-1240, 2002.

MINSON, D.J. Forage in Ruminant Nutrition. San Diego: Academic Press, 1990. 483p.

MORAES, E.H.B.K.; PAULINO, M.F.; ZERVOUDAKIS, J.T.; VALADARESFILHO, S.C.; MORAES, K.A.K. Avaliação Qualitativa da Pastagem Diferida de Brachiaria decumbens Stapf., sob Pastejo, no Período da Seca, por Intermédio de Três Métodos de Amostragem. Revista Brasileira de Zootecnia, v.34. n,1, p.30-35, 2005. 
NASCIMENTO, M.L.; PAULINO, M.F.; DETMANN, E.; LEÃO, M.I.; VALADADRES FILHO, S. de C.; HENRIQUES, L.T. Fontes de energia em suplementos múltiplos para novilhos em pastejo durante o período das águas. Revista Brasileira de Zootecnia, v.39, n.4, p.861-872, 2010.

PASCHOALOTO, J.R.; EZEQUIEL, J.M.B.; ALMEIDA. M.T.C.; FÁVARO, V.R.; HOMEM JÚNIOR, C.; CARVALHO, V.B.; PEREZ, H. L. Inclusion of crude glycerin with different roughages changes ruminal parameters and in vitro gas production from beef cattle. Ciência Rural, v.46, n.5, p.889-894, 2016.

PERIPOLLI, V.; PRATES, Ê.R.; BARCELLOS, J.O.J.; WILBERT, C.A.; CAMARGO, C.M.; LOPES, R.B.; COSTA JUNIOR, J.B.G. Effect of crude glycerol on in vitro ruminal fermentation kinetics. Revista Brasileira de Saúde e Produção Animal [online], v.15, p.172-181, 2014.

RAMOS, M.H.; KERLEY, M.S. Effect of dietary crude glycerol level on ruminal fermentation in continuous culture and growth performance of beef calves. Journal of Animal Science, v.90, p.892-899, 2012.

SAUER, F.D.; ERFLE, J.D.; FISHER, L.J. Propylene glycol and glycerol as a feed additive for lactating dairy cows: an evaluation of blood metabolite parameters, Journal of Animal Science, v.53, p.265-271, 1973.

SILVA MARQUES, R.P. ZERVOUDAKIS, J.T.; HATAMOTOZERVOUDAKIS, L. K.; CABRAL, L.S.; ALEXANDRINO, E.; MELO, A.C.B.; SOARES, J.Q.; DONIDA, E.R.; SILVA, L.C.R.R. Suplementos múltiplos para novilhas de corte em pastejo no período seco. Semina:

Ciências Agrárias, v.36, n.1, p.525540, 2015.

SILVA, F.F.; SÁ, J.F.; SCHIO, A.R.; VINHA, L.C.; SILVA, R.R.; MATEUS, R.G. Suplementação a pasto:

disponibilidade e qualidade $\mathrm{x}$ níveis de suplementação x desempenho. Revista Brasileira de Zootecnia, v.38, p.371389, 2009.

VALADARES FILHO, S. de C.; PINA, D. dos S. Fermentação ruminal. In: BERCHIELLE, T.T.; PIRES, A.V.; OLIVEIRA, S.G. de. Nutrição de ruminantes. Jaboticabal: Funep, 2006. $583 p$.

VALADARES FILHOS, S. de C.; MARCONDES, M.I.; CHIZZOTTI, M.L.; PAULINO, P.V.R. Exigência Nutricionais de Zebuínos Puros e Cruzados - BR- CORTE. 2.ed. Viçosa, MG: UFV, 2010. 193p.

VAN SOEST, P.J. Nutritional Ecology of the Ruminant. 2.ed. Ithaca: Cornell University, 1994. 476p.

WILLIANS, C.H.; DAVID, D.J.; IISMA, O. The determination of chromic oxide in faeces samples by atomic absorption spectrophotometry. Journal of Agricultural Science, v.59, n.3, p.381-385, 1962.

Data de recebimento: 11/06/2017

Data de aprovação: 14/11/2017 